\title{
Correction: Structural Racism and Supporting Black Lives - A Pharmacist's Vow amid COVID-19
}

Nicole D. Avant, PharmD, BCACP

University of Cincinnati Experience-Based Learning and Career Education

An earlier version of this article (https://doi.org/10.24926/iip.v12i2.3411) included a layout error that misnumbered the references, resulting in errors for references $16-36$. The reference list should read as follows:

\section{References}

1. US Census Bureau Quick Facts: United States. Available online:

https://www.census.gov/quickfacts/fact/table/US/PS\%20T $\underline{045219}$ (accessed on 13 May 2020).

2. Cases in the US. Available online:

https://www.cdc.gov/coronavirus/2019-ncov/casesupdates/cases-in-us.html (accessed on 13 May 2020).

3. COVIDView A Weekly Surveillance Summary of US COVID19 Activity. Available online: https://www.cdc.gov/coronavirus/2019-ncov/coviddata/covidview/index.html (accessed on 13 May 2020).

4. Provisional Death Counts for Coronavirus Disease (COVID19): Weekly Updates by Select Demographic and Geographic characteristics. Available online: https://www.cdc.gov/nchs/nvss/vsrr/covid weekly/i ndex.htm\#Race Hispanic (accessed on 13 May 2020).

5. Opinion | Why Coronavirus Is Killing African- Americans More Than Others. Available online: https://www.nytimes.com/2020/04/14/opinion/sund ay/coronavirus-racism-african- americans.html?auth=loginfacebook (accessed on 13May 2020).

6. Health Factors | County Health Rankings and Roadmaps. https://www.countyhealthrankings.org/explore- healthrankings/measures-data-sources/county- health-rankingsmodel/health-factors (accessed on13 May 2020).

7. Auburn A, Brown A, Grady J. External Factors vs. Right Choices: Findings From Cognitive Elicitations and Media Analysis on Health Disparities and Inequities. Louisville, KY: Cultural Logic; 2007.

8. Jones C. Levels of racism: a theoretic framework anda gardener's tale. American Journal of Public Health. 2000;90(8):1212-5.

9. Williams DR, Williams DR, Mohammed SA, Mohammed SA. Discrimination and racial disparitiesin health: evidence and needed research. Journal ofBehavioral Medicine. 2009;32(1):20-47.

10. Black People Are Dying From COVID-19 at Higher Rates Because Racism Is a Preexisting Condition. Available online: https://www.motherjones.com/coronavirusupdates/2020/04/black-people-are-dying-from-covid- 19-athigher-rates-because-racism-is-a-pre-existing- condition/ (accessed on 13 May 2020).

11. Banaji MR, Greenwald AG. Blindspot: hidden biases ofgood people. 1st ed. New York: Delacorte Press; 2013.

12. Hardeman RR, Medina EM, Kozhimannil KB. Structural Racism and Supporting Black Lives - TheRole of Health Professionals. The New England Journal of Medicine. 2016;375(22):2113-5.
13. Oath of a Pharmacist | American Pharmacists Association. Available Online: https://www.pharmacist.com/oathpharmacist(accessed on 13 May 2020).

14. Metzl JM, Roberts DE. Structural competency meets structural racism: race, politics, and the structure ofmedical knowledge. The virtual mentor: VM. 2014;16(9):674-90.

15. Accreditation standards and key elements for the professional program in pharmacy leading to the doctor of pharmacy degree ("Standards 2016"). Accreditation Council for Pharmacy Education; 2 February 2015 Accessed 4 Aug 2020 https://www.acpeaccredit.org/pdf/Standards2016FIN AL.pdf

16. Flint city, Michigan; United States. Available online: https://www.census.gov/quickfacts/fact/table/flintcit ymichigan,US/PST045219 (accessed on 13 May 2020).

17. Flint Water Crisis: Is the Water Clean Now? Availableonline: https://www.npr.org/2019/04/25/717104335/5- yearsafter-flints-crisis-began-is-the-water-safe https://www.cnn.com/2016/03/04/us/flint-water- crisisfast-facts/index.html (accessed on 13 May 2020).

18. Lead: Health Problems Caused by Lead - NIOSH Workplace Safety and Health Topic. Available online: https://www.cdc.gov/niosh/topics/lead/health.html (accessed on 13 May 2020).

19. Joint Statement on the Response to the Coronavirus/COVID-19 Pandemic. Available online: https://www.nmanet.org/news/503170/Joint- Statementon-the-Response-to-the- CoronavirusCOVID-19Pandemic.htm (accessed on 13May 2020).

20. CDC Reverses Course Again On Using Race As Testing Criteria. Available online: https://www.wvxu.org/post/cdcreverses-course- again-using-race-testing-criteria\#stream $/ 0$ (accessedon 13 May 2020)

21. Interim Guidance: Healthcare Professionals 2019- nCoV. Available online: https://www.cdc.gov/coronavirus/2019ncov/hcp/clinical-criteria.html (accessed on 13 May2020).

22. COVID-19: Investing in black lives and livelihoods. Available online:

https://www.mckinsey.com/ /media/mckinsey/industries/ public\%20and\%20social\%20sector/our\%20insights/covid\%2 019\%20investing\%20in\%20black\%20lives\%20and\%20livelih oods/covid-19-investing-in-black-lives-and-livelihoodsreport.pdf (accessed on 13 May 2020)

23. New York City's Frontline Workers. Available online: https://comptroller.nyc.gov/reports/new-york-citysfrontline-workers/ (accessed on 13 May 2020).

24. Gap between number of blacks, whites in prison narrows. Available online: https://www.pewresearch.org/facttank/2019/04/30/shrinking-gap-between-number-ofblacks-and-whites-in-prison/ (accessed 13 May 2020). 
25. Racial Disparities in Homelessness in the United States National Alliance to End Homelessness. Available online: https://endhomelessness.org/resource/racial-inequalitieshomelessness-numbers/ (accessed on13 May 2020).

26. Opinion: Race Disparities Built In To COVID-19 Treatment Guidance For Hospitals: Shots - Health News. Available online: https://www.npr.org/sections/healthshots/2020/04/21/838763690/opinion-u-s-must- avoidbuilding-racial-bias-into-covid-19-emergency- guidance (accessed on 13 May 2020).

27. Framing Questions on Intersectionality. Available online: https://ushrnetwork.org/uploads/Resources/framing questi ons on intersectionality 1.pdf (accessed 13 May 2020).

28. Avant ND, Gillespie GL. Pushing for health equity through structural competency and implicit bias education: A qualitative evaluation of a racial/ethnichealth disparities elective course for pharmacy learners. Currents in Pharmacy Teaching and Learning. 2019;11(4):382-93.

29. Avant ND, Weed E, Connelly C, Hincapie AL, Penm J. Qualitative Analysis of Student Pharmacists' Reflections of Harvard's Race Implicit Association Test. Currents in Pharmacy Teaching and Learning. 2018;10(5):611-7.

30. Avant ND, Davis RD. Navigating and SupportingMarginalized Identities in Dominant Pharmacy Spaces. Innov Pharm. 2019; 9(4).

31. Avant, ND, Penm J, Hincapie AL, Gillespie GL. "Not to Exclude You, But...": Characterization of Pharmacy Student Microaggressions and Recommendations forAcademic Pharmacy. Curr Pharm Teach Learn. 2020; 12(10):11711179.

32. Clinical Care. Available online: https://www.countyhealthrankings.org/explore- healthrankings/measures-data-sources/county- health-rankingsmodel/health-factors/clinical-care (accessed on 13 May 2020).

33. Arya V, Butler L, Leal S, et al. Systemic racism: Pharmacists' role and responsibility. Journal of the American Pharmacists Association. 2020;60:e43-e46.

34. Jones CP, Jones CY, Perry GS, Barclay G, Jones CA. Addressing the Social Determinants of Children's Health: A Cliff Analogy. Journal of Health Care for thePoor and Underserved. 2009;20(4):1-12.

35. COVID-19: A Human Rights Checklist. Available online: https://www.hrw.org/news/2020/04/14/covid-19- humanrights-checklist (access 13 May 2020).

36. Crear-Perry J, Correa-de-Araujo R, Lewis Johnson T, McLemore MR, Neilson E, Wallace M. Social and Structural Determinants of Health Inequities in Maternal Health. Journal of women's health (Larchmont, N.Y. 2002). 2021;30:23-235. 